\title{
Hearing their voices and counting them in: The place of Canadian LGBTQ police officers in police culture
}

\author{
Joe L. Couto*
}

\begin{abstract}
The growing presence of LGBTQ police officers and civilian personnel within police organizations, their presence at LGBTQ community events, increased recruitment efforts, and the emergence of LGBTQ advocacy groups within policing invites research into the lived experiences of these police service members. My 2014 study of 21 LGBTQ sworn police officers in Ontario revealed that most officers believe their status and relationships in their workplaces are more positive today compared to other eras. However, it also found that they believe that police culture fundamentally retains a hypermasculine and heterosexual orientation. A subsequent study of the intersectionality of gender and sexual orientation for gay female sworn police officers found that being "female" and being "gay" exposes LGBTQ female police officers to challenges regarding both their gender and their sexual orientation-specifically workplace harassment and having to conform to masculine "norms". However, the research also suggests that these and other challenges in a police environment based on sexual orientation are not as overt as those based on gender alone. Understanding such subtle differences is vital to creating inclusive and supportive work environments in which LGBTQ members can thrive and contribute as their authentic selves and find legitimacy and respect as police professionals.
\end{abstract}

Key Words Policing; police culture; LGBTQ; diversity; organizational culture

Journal of CSWB. 2018 Dec;3(3):84-87

www.journalcswb.ca

\section{INTRODUCTION}

Lesbian, gay, bisexual, transgender, and queer (LGBTQ) police service members have become increasingly visible as Chiefs of Police, senior supervisors and managers, front-line police officers, and civilian personnel. Moreover, as these police officers and civilian personnel and their workplace allies have come to embrace LGBTQ community events such as Pride Parades, and many services have established dedicated personnel to liaise and recruit from within their LGBTQ communities, their visible presence has required police leaders to confront law enforcement's troubled past regarding LGBTQ communities. It has also reopened debate within LGBTQ communities about embracing police personnel as part of these communities.

In the 1950s and 1960s, LGBTQ activists resisted police repression of their personal lives, largely centred on bars, which served as "the primary social institution" of LGBTQ life after World War II (Armstrong \& Carge, 2006, p. 728). Police oppression was commonplace prior to the famous Stonewall Riots of the early 1970s in New York City and reflected the hypermasculine and heterosexual orientation of policing. In Canada, such events as the 1981 Toronto Bathhouse Raids (Kirkup, 2013) and the Ottawa Police Service's 2010 Steven Boone HIV non-disclosure press release (HIV \& AIDS Legal Clinic Ontario, 2013) are examples of events that have aggravated tensions between police and LGBTQ communities.

\section{Review of Literature on the Experiences of LGBTQ Police Officers}

The increased visibility on the part of LGBTQ sworn police officers in their own workplace reflects a shift in Western society since the 1970s when LGBTQ individuals increasingly fought for their legal rights. As the broader culture changed to be more accepting of LGBTQ individuals, so has the police culture, which is deeply rooted and applicable to all police organizations, slow to change in its fundamental assumptions, and strongly defined by values and beliefs that are continuously reinforced to its members (Skolnick, 2008). Researchers such as Franklin (2007) and Collins (2015) have described the culture as heterosexual and hypermasculine 
in character, which has produced organizations that Miller, Forest, \& Jurik (2003) labelled as "white, working class, male enclaves".

Like all police organizational members, LGBTQ sworn police officers and civilian personnel face pressures to conform to the police culture; to adhere or conform to the culture of his or her police organization's prevailing beliefs and values, which are passed onto new members and reinforced to current members through a series of "complex ensembles of values, attitudes, symbols, rites, recipes, and practices" that are unique to the law enforcement profession (Reiner, 2010, p. 116). In particular, research on the lived experiences of LGBTQ sworn police officers has generally concluded that they often live dual lives: their private life based on their sexual orientation and gender identity, and their professional life as a police officer (Burke, 1994; Miller et al., 2003). Burke (1995) specifically argued that an LGBTQ police officer's ability to function openly within a police structure that is based on heterosexuality as the norm produced double, as opposed to integrated, lives.

The impact of the police culture is critical to understanding the lived experiences of LGBTQ sworn police officers. Most academic research into police culture sees it either as (1) a hegemonic monolith that encompasses all police officers, or (2) a series of subcultures (Paoline, 2004). The monolithic approach argues that police culture demands conformity through socialization, where officers are initiated into a police "brotherhood" as part of their training, socialize with one another, and tend to exclude non-police from their interaction; and solidarity, where officers develop a sense of "brotherhood", the "blue line", and "having one another's back" (Skolnick, 1994, pp. 48, 52). Typically in this frame, police officers are seen as a "cynical, authoritative, and isolated group of people who have low self-esteem and feel they receive little respect" (Carter \& Radlet, 1999, p. 166) and who resist challenges to the traditional status quo.

On the other hand, the subculture approach considers police culture as made up of subcultures with greater diversity and social variability than previously thought (Nickels \& Verma, 2007) and that the traditional "cop" pictured in the monolithic approach may be just one of many subcultures or groups within modern police organizations (Paoline, 2004). According to Nickels \& Verma (2007), these subcultures are impacted by management styles, policing philosophies, organizational traditions, shifting social-economic changes in society related to the shift toward community policing as a philosophy, as well as new demographics within police organizations (Colvin, 2012). Research on specific groups or subcultures within policing is increasingly common today (Colvin, 2012; Hassell \& Brandl, 2009).

\section{Insights from LGBTQ Police Officers}

In 2014, I completed a study of LGBTQ sworn police officers in the Province of Ontario. This study was based on data from 21 open-ended interviews with officers. The use of interviews has been effectively used (Burke, 1994; Rumens and Broomfield, 2012) to explore why LGBTQ police officers choose a law enforcement career and to explore their experiences. One-on-one interviews, in particular, produce contextual cues such as commonly used words or phrases or common experiences that provide insight into perceptions (e.g., how they assessed police culture, how their personal values aligned with the espoused values of their organizations, the impact of the dominant police culture on their careers, training, and promotional opportunities). I also analyzed seven types of artifacts from 16 police organizations: police service mottos, business plans, strategic plans, mission/vision statements, policies, uniforms, and polices related to physical structures of police facilities. This analysis provided further insight into the qualitative data derived from the interviews, and illuminated the role that discourse plays in reinforcing police culture.

The combined analysis of the interviews with 21 LGBTQ sworn police officers and study of the police artifacts revealed a number of key findings:

While participants generally agreed that police culture is still conservative and male-dominated, most also agreed that it has evolved toward inclusivity over the past 20 years as more women, members of racialized groups, and LGBTQ individuals have been recruited and have risen through the ranks;

- Young, heterosexual recruits tend not to have a condemnatory attitude toward their LGBTQ peers. Study participants generally believed that organizational resistance toward inclusivity in their services centred primarily on middle managers, 50 years of age and older, who retain more traditional and negative attitudes toward LGBTQ police officers;

- While some participants reported experiencing overt discrimination and harassment during their careers, most report a greater presence of "microaggressions" in the workplace (e.g., inappropriate jokes);

- Participants confirmed a number of findings from other studies: exhibiting a "working personality" where they strive to become "prototypical cops" (Skolnick, 2008); tending to lead "dual lives" where their work and their sexual selves are largely separated (Burke, 1994; Miller et al., 2003); and, female officers emphasized "shared perceptions" that incorporate their gender challenges, as well as their sexual orientation, into how they must negotiate their workplace and career experiences (Colvin 2012 and 2015);

- Participants expressed concern about the disconnection between what organizations say (often expressed through artifacts) and how "things really are" in the workplace. The police culture's continued emphasis on solidarity and secrecy leaves it vulnerable to abuse of authority and resistant to organizational change (Waddington, 1999);

- The study found strong support among participants for policing as a profession and for their own organizations in particular. This indicates that policing as a profession maintains a strong ability to bind its members to its goals of law enforcement and crime prevention regardless of their personal characteristics. In fact, most had no fundamental disagreement with the generally conservative values, beliefs, and assumptions of their services as they relate to law enforcement and crime prevention; and

- Participants confirmed what Hassell \& Brandl (2009) identified as the most common workplace problem 
experienced by officers in general: the lack of support and influence that officers experienced or had in the workplace.

\section{Preliminary Insights from LGBTQ Female Officers}

In 2018, I completed a more specific, preliminary study of LGBTQ female sworn police officers funded by the University of Guelph-Humber. This research flowed out of the 2014 study as a result of female LGBTQ police service members urging me to explore the intersectionality of gender and sexual orientation in policing. Specifically, I posited that female police officers who identify as LGBTQ face additional challenges when compared to their heterosexual, female counterparts because their experiences as LGBTQ female officers may be co-determined by their gender and their sexual orientation (Boogaard \& Roggeband, 2010).

A total of 40 female LGBTQ police officers completed a survey on their lived experiences. Subsequently, 10 survey respondents participated in two focus groups to further consider their lived experiences. The research found that being "female" and being "gay" exposes police officers to some similar challenges in terms of both their gender and their sexual orientation-specifically, workplace harassment and having to conform to masculine "norms" (e.g., act tough) (Galvin-White \& O'Neal, 2016; Jones \& Williams, 2015). However, the research also suggests that these and other challenges in a police environment based on sexual orientation are not as overt as those based on gender alone. This may be due to one's sexual orientation not being a "visible" characteristic (as gender or race would be) and, thus, less subject to overt harassment and other negative workplace experiences.

\section{Questions Arising from LGBTQ Police Officers' Experiences}

The lived experiences of LGBTQ police officers in Canada remains an area of academic study deserving of further and greater urgency of research, particularly with the increasing numbers of "openly gay" officers joining policing. The emergence of LGBTQ advocacy groups within policing (e.g., Serving With Pride) and greater number of LGBTQ members serving at the highest levels of police organizations calls for the consideration of their experiences. LGBTQ police officers consistently express pride in their profession, and a desire for acceptance and respect from their peers.

The question of intersectionality of sexual orientation with other personal characteristics (e.g., race) is an area open to expanded research, as are the specific experiences of all LGBTQ police officers (e.g., transgender, two-spirited). With greater diversity in police services reflecting the communities they serve, understanding, affirming, and supporting the lived experiences and values of LGBTQ and other members who may not fit as readily into "traditional" policing "norms" will present a continuing and urgent challenge for police leaders and police service members alike. In an era where police legitimacy and even relevance is increasingly called into question, LGBTQ members of police organizations must also find legitimacy and respect as police professionals and play an active role in the future of policing in Canada.

\section{ACKNOWLEDGMENTS}

The author wishes to acknowledge the support of the University of Guelph-Humber for providing a grant in support of his research on LGBTQ female police officers.

\section{CONFLICT OF INTEREST DISCLOSURES}

The author states that there are no conflicts of interest.

\section{AUTHOR AFFILIATIONS}

*School of Communication and Culture, Royal Roads University, Victoria, BC; Justice Studies, University of Guelph-Humber, Toronto; Ontario Association of Chiefs of Police, Toronto, ON.

\section{REFERENCES}

Armstrong, E. A. \& Crage, S. M. (2006). Movements and memory: The making of the Stonewall myth. American Sociological Review, 71, 724-751. Retrieved from https://ezproxy.royalroads.ca/login?url=http://search. proquest.com.ezproxy.royalroads.ca/docview/218801384?accoun tid=8056. Available from: http://journals. sagepub.com/doi/abs/10 $.1177 / 000312240607100502$ \#articleCitationDownloadContainer

Boogaard, B., \& Roggeband, C. (2010). Paradoxes of intersectionality: Theorizing inequality in the Dutch police force through structure and agency. Organization, 17, 53-75. doi.org/10.1177/1350508409350042

Burke, M. (1994). Homosexuality as deviance: The case of the gay police officer. British Journal of Criminology, 34, 192-203

Burke, M. (1995). Identities and disclosures: The case of lesbian and gay police officers. The Psychologist, 8, 543-547.

Carter, D. L. \& Radlet, I. (1999). The police and the community (6 $6^{\text {th }}$ ed.). New York, NY: Prentice-Hall.

Collins, J. C. (2015). Characteristics of "masculinized" industries: Gay men as a provocative exception to male privilege and gendered rules. Human Resource Development Review, 14, 415-441. doi:10.1177/1534484314559930

Colvin, R. (2012). Gay and lesbian cops: Diversity and effective policing. Boulder, CO: Lynne Rienner Publishers Inc.

Colvin, R. (2015). Shared workplace experiences of lesbian and gay police officers in the United Kingdom. Policing, 38, 333-349. doi.org/10.1108/ PIJPSM-11-2014-0121

Franklin, C. A. (2007) Male peer support and the police culture: Understanding the resistance and opposition of women in policing. Women \& Criminal Justice, 16, 1-25. doi:10.1300/J012v16nO3_01

Galvin-White, C. \& O'Neal, E. N. (2015). Lesbian police officers' interpersonal working relationships and sexuality disclosure: A qualitative study. Feminist Criminology, 11, 253-284. doi.org/10.1177/1557085115588359

Hassel, K. D. \& Brandl, S. G. (2009). An examination of the workplace experiences of police patrol officers: The role of race, sex, and sexual orientation. Police Quarterly, 12, 408-430. doi.10.1177/1098611109348473

HIV \& AIDS Legal Clinic Ontario. (2013). The criminalization of HIV non-disclosure: Recommendations for police, 1-16. Toronto, ON: Can HIV/AIDS Legal Network. Retrieved from http://www.aidslaw.ca/site/the-criminalization-of-hiv-non-disclosure-recommendations-for-police/?̣lang=en

Jones, M. \& Williams, M. (2015). Twenty years on: Lesbian, gay and bisexual police officers' experiences of workplace discrimination in England and Wales. Policing and Society, 25, 188-211

Kirkup, K. (2013). Best practices in policing and LGBTQ communities in Ontario. Toronto, ON: Ontario Association of Chiefs of Police. Retrieved from http://www.oacp.on.ca/news-events/news-releases/ontarios-policechiefs-unveil-best-practices-guidelines-for-police-serving-lgbtq-communities

Miller, S. L., Forest, K. B., \& Jurik, N. C. (2003). Diversity in blue: Lesbian and gay police officers in a masculine occupation. Men and Masculinities, 5, 355-385. doi:10.1177/0095399702250841.

Nickels, E. \& Verma, A. (2007). Dimensions of police culture: A study in Canada, India, and Japan. Policing: An International Journal of Police Strategies \& Management 31, 186-209. doi:10.1108/13639510810878686 
Paoline, E. A. (2004). Shedding light on police culture: an examination of officers' occupational attitudes. Police Quarterly 7, 205-236. doi:10.1177/1098611103257074

Reiner, R. (2010). The politics of the police (4th ed.). New York, NY: Oxford University Press.

Rumens, N. \& Broomfield, J. (2012). Gay men in the police: Identity disclosure and management issues. Human Resource Management Journal, 22, 283-298. doi:10.111/j.1748-8583.2011.00179.x.
Skolnick, J. H. (1994). Justice without trial: Law enforcement in a democratic society ( $3^{\text {rd }}$ ed.). New York, N.Y: MacMillian.

Skolnick, J. H. (2008). Enduring issues of police culture and demographics. Policing and Society: An International Journal of Research and Policy, 18, 35-45. doi.10.1080/10439460701718542

Waddington, P. A. J. (1999). Police (canteen) sub-culture. British Journal of Criminology, 39, 287-309. doi:10.1093/bjc/39.2.287 